DOI: https://doi.org/10.31933/dijemss.v2i2

Received: 1 November 2020, Revised: 15 November 2020, Publish: 24 December 2020

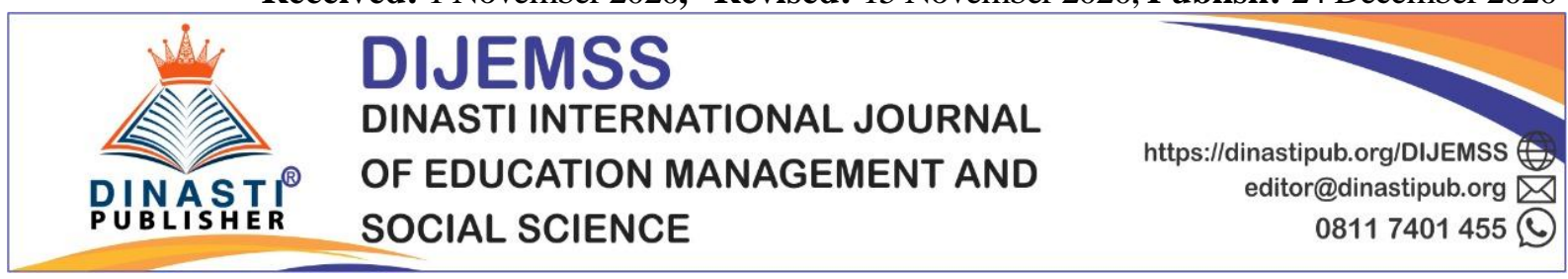

\title{
FINANCIAL PERFORMANCE ANALYSIS AT PT. MANDIRI SYARIAH BANK
}

\author{
Akhmadi $^{1}$, Sumantri ${ }^{2}$, Albetris ${ }^{3}$ \\ ${ }^{1)}$ Lecturer at STIE Graha Karya Muara Bulian, Jambi, Indonesia, h.akhmadijambi@gmail.com \\ ${ }^{2)}$ Lecturer at STIE Graha Karya Muara Bulian, Jambi, Indonesia, Sumantri.baharun123@ gmail.com \\ ${ }^{3)}$ Lecture of Universitas Batanghari, Jambi, Indonesia, Albetris90@gmail.com
}

\section{Corresponding Author: First Author}

\begin{abstract}
Analysis of the Growth of the Liquidity Ratio, Solvency, and Profitability, the objectives are, namely, the first is to determine the condition of the Growth of the Liquidity Ratio of PT. Bank Syariah Mandiri Indonesia for the period 2014-2018. The second is to determine the condition of the Growth of the Solvency Ratio of PT. Bank Syariah Mandiri Indonesia for the period 2014-2018. The third is to determine the Growth of the profitability ratio at PT. Bank Syariah Mandiri Indonesia for the period 2014-2018. And lastly, to determine the condition of the Growth of the Liquidity Ratio, Solvency, and Profitability with a financial performance at PT. Bank Syariah Mandiri Indonesia for the period 2014-2018. Based on the results of research conducted at PT. Bank Syariah Mandiri Indonesia it can be concluded that the average growth Liquidity Ratio 2014-2018 period be seen from the Current Ratio approach amounted to $1,32 \%$. seen from the average Growth of the Solvency Ratio for the 2014-2018 period of (1) \%. And the Growth of the Profitability Ratio for the 2014-2018 period is seen from the average Growth of Net Profit Margin of 140, $04 \%$. Return On Investment. For an average Growth of 208, $02 \%$. Return On Equity has an average Growth value of 192, $48 \%$.
\end{abstract}

Keywords: Bank, Growth, Financial Performance

\section{INTRODUCTION}

The level of growth of Islamic Banking in Indonesia is based on indirect observation is very fast, but with a scale comparable with the previous conditions, but when compared with the conventional banking, the number of Islamic banking is still very small, and the growth of Islamic banking is feasible because of the number of the Muslim population there are many in the Republic of Indonesia.

Banking is the lifeblood of the economy throughout the country, many wheels of the economy especially in the move by the banks either directly or indirectly. Banking in Indonesia plays a very important role, especially as Indonesia is a country that is developing in all sectors. It explains late in Article 4 of Law No. 10 of 1998, namely Indonesian banking aims to support the implementation of national Growth to increase equity, economic growth, and national stability towards the improvement of the people at large.

A bank is said to be successful in winning its business competition if it can provide bank financial services better than its competitors by observing and analyzing the company's financial 
performance through financial reports. Economic growth as it is today, one of the most prominent aspects is in the financial industry sector (Sumantri, 2020) The financial report is one of the tools used to determine the company's financial performance which is compiled at the end of each period which contains overall financial accountability. In analyzing financial statements, financial analysis tools are needed, one of which is by using financial ratios. The financial ratios include the Liquidity Ratio, Solvency Ratio, and Profitability Ratio. Expected with analysis can be known so that the company's financial performance report finance can be considered a natural decision, especially for directors in setting policy.

The banking industry is now continuing to expand its business and is required to improve its performance, given the increasingly fierce competition from its competitors. Islamic banking emerged in Indonesia in 1992 which is a new thing in the framework of the banking system mechanism in general. The more Growth of Islamic banking in Indonesia, there is a growing need for socialization of what and how the operations of Islamic banks are. Because the operations of Islamic banking are very different from conventional banking.

An Islamic bank is a financial institution that underlies its banking operations following aspects of the lives of that $\mathrm{n}$ the economic basis of the Qur ' an and As-Sunnah. None other than the main objective of establishing a sharia bank, so that Muslims can live a life by sharia in all aspects without exception in banking activities. Sa was one Islamic Bank that has an important role in the growth of Islamic Banking in Indonesia is Bank Syariah Mandiri.

Bank Syariah Mandiri was formed due to the conversion of the business activities of Bank Susila Bakti (BSB) to a sharia commercial bank which was confirmed by the Governor of Bank Indonesia through the Decree of the Governor of BI No.1 / 24 / KEP.BI / 1999, October 25, 1999. Furthermore, through a Decree Senior Deputy Governor of Bank Indonesia 1/1 / KEP.DGS / 1999, BI accepted the change its name to PT Bank Syariah Mandiri. Following the inauguration and legal recognition, PT Bank Syariah Mandiri officially began operating on Monday 25 Rajab 1420 H or November 1, 999.

PT. Bank Syariah Mandiri is a subsidiary of Bank Mandiri, the largest state-owned bank in Indonesia. Bank Syariah Mandiri is one of the sharia banking institutions in Indonesia that continues to grow. Therefore, amidst rampant competition with other banks, financial performance must always be maintained so that customer trust does not decline in the company.

According to V. Wiratna Sujarweni, assessing a bank's financial performance uses four analysis tools, namely liquidity ratio analysis, solvency ratio, activity ratio, and profitability ratio. However, in this case, the authors only use three analyzes including the Liquidity Ratio, Solvency Ratio, and Profitability Ratio. Because for the author the Activity Ratio is used to measure the level of company wealth while at PT. Bank Syariah Mandiri wealth value is still relatively small compared to state-owned banks such as Bank Mandiri the parent of Bank Syariah Mandiri and other large private banks. This is because PT. Bank Mandiri Syariah is still relatively still young and newly founded in 1999.

Table 1. The State of Cash, Capital and Debt at PT. Bank Syariah h Mandiri Indonesia for the period 2014-2018 in million rupiahs $(000,000)$

\begin{tabular}{cccc}
\hline Year & Cash $(\mathbf{R p})$ & Capital $(\mathbf{R p )}$ & Debt $(\mathbf{R p )}$ \\
\hline 2014 & 1.513 .580 & 4.617 .009 & 8.663 .174 \\
2015 & 1.611 .125 & 5.613 .739 & 9.883 .107 \\
2016 & 1.086 .569 & 6.392 .437 & 11.232 .797 \\
2017 & 1.135 .610 & 7.314 .241 & 13.506 .681
\end{tabular}




\section{$\begin{array}{cccc}2018 & 1.324 .081 & 8.039 .165 & 14.477 .262 \\ \text { Source: Annual Report PT. Bank Syariah Mandiri Indonesia for the period 2014-2018 }\end{array}$}

The discussion of financial performance in this study is limited to Liquidity Ratios, Solvability, and Profitability. Based on the background description above, the authors are interested in making PT. Bank Syariah Mandiri as the object of research.

\section{LITERATURE REVIEW}

The performance of commercial bank analysis has been carried out by many researchers in various countries. The performance analysis of Islamic and conventional bank is done to understand the effectiveness of the banking system. Researcher has considered various articles on bank performance in Bahrain and other countries of the world to have more comprehensive analysis. Raquibuz Zaman and Hormoz Movassaghi (2001) opined that the products and services offered by the Islamic banks do not conform to the traditional Islamic principles. Emphasizing on profitability is concern, Haron (2004) revels that expenditures and profitability are positively correlated and the size of the Islamic banks only had a significant positive correlation with expenditure but was not significant with profitability measures. Chen et. al., (2005) found the large state-owned banks and smaller banks are more efficient than medium sized among Chinese commercial banks. Their study also opined that, technical efficiency consistently dominates the locative efficiency among commercial banks in China. Burhonov (2006) found that there is no clear-cut relation between short-term funding and profitability. Interestingly their regression analysis reveals that the impact of macroeconomic variables, GDP on profitability is not conclusive. Noor Ahmed Memon (2007), opines that the role of Islamic banks as financial mediators and its importance to the society is very relevance. The study reveals that Islamic Banks entering directly into areas like trade\& commerce, industry and agriculture etc. is not beneficial as it implies that banks are deviating from their actual role as a financial intermediary. Alkassim (2007) opined that the return on Assets for Islamic banks in GCC has positive correlation with total assets and total expenses. In contradiction to (Burhonov 2006) result, Zantioti (2009) in their study reveals that equity to total assets and GDP per have a significantly positive impact on profitability of Islamic bank. Usman et. al., (2009) opines that the financial reforms improved the level of efficiency in banking sector in Pakistan. Hameeda Abu Hussain and Jasim Al-Ajmi (2012) opined that the credit, liquidity and operational risk are very important risks facing both Islamic and conventional banks.

Kaleem (2000) opined that the Islamic banking system is more crises-proofed compared to the conventional banking system due to its asset-linked nature. Mathuva (2009) found a negative relationship between the equity capital ratio and profitability. Their study also reveals that in terms of their efficiency as measured by the cost to income ratio Kenyan banks are not globally competitive enough. Kassim and Majid (2010) finds mixed evidences on the impact of the macroeconomic shocks on the Islamic and conventional banks and their study also indicated that the Islamic banks are relatively resilient to the financial shocks, the results based on the more robust econometric analysis reveal otherwise. Further the results based on the IRF analysis show that the Islamic financing responded significantly to macroeconomic shocks in non-crisis and 2007 crisis periods. Iqbal and Joseph (2011a) revealed that among the factors affecting selection of the banks, people give top most priority 
to reliability, human element at the second position, responsiveness at the third position, accessibility at the fourth position, and tangibility in the fifth position respectively. Iqbal and Joseph (2011b) opined that the most crucial factor leading to service gap is systemization or technological advancement among interactive and conventional banks. Najjar (2013) found that the variations in profitability of five Bahraini banks for the years 2005, 2006 and 2007, were satisfactory for the due to good profit margins generated in those years. While in 2008 and 2009, poor profit margins had a significant impact on ROE. Palečková (2014) examined the relationship between profitability and efficiency in the Czech banking sector using Granger causality test and concludes that Ganger Causality do not confirm the relationship between Return on Equity, Return on Assets on efficiency of the banks. Hawaldar et. al., (2016a) found that operating efficiency of wholesale Islamic banks was better than retail Islamic banks for the period of 2009-2013, which was evident from asset utilization ratio. Using the result of correlation analysis of wholesale Islamic banks between various performance indicators, their study also showed the existence of significant positive correlation of cost to income ratio with operational efficiency ratio and staff cost to income ratio. A similar study by Hawaldar et. al., (2016b) opined that no significant difference between the performance of retail and wholesale conventional banks operating in Bahrain. Hawaldar et. al., (2016c) revealed that team orientation and development is the crucial aspect in enhancing employees' performance. The study opines that the leadership affect the performance of the banks in Bahrain.

Hawaldar et. al., (2017a) analysed the impact of financial and oil price crisis on the financial performance of selected banks in Bahrain. They selected a sample of seven commercial banks out of which three Islamic banks and four conventional banks. The study covered a period of eleven years, from 2005 to 2015. The financial performance of banks in terms of profitability, efficiency, leverage and liquidity is analysed through ratios. They found that there was not much impact on the financial performance of the banks during the crisis and pre-crisis period but the impact was observed in post financial crisis. The oil price crisis has an impact on the financial performance of banks all the banks. Hawaldar et. al., (2017b) examined the impact of oil crisis on the performance of selected banks of Kingdom of Bahrain using profitability, efficiency, capital adequacy and liquidity ratios in the precrisis and crisis periods. The study reveals that there is no significant difference in the performance of banks in the pre-crisis and crisis period. The results indicate that there is a significant difference in the performance of conventional banks and Islamic banks in the precrisis period. Hawaldar et. al., (2017c) revealed that conventional retail banks, except for Bahrain development bank, have consistent performance in return on assets and return on equity. While among the Islamic retail banks, the performance of Kuwait finance house is satisfactory in terms of profitability. Hawaldar et. al., (2017d) found that the staff cost to income ratio, cost to income ratio, asset utilization and operating efficiency is higher in wholesale Islamic and conventional banks compared to retail banks. They also found that there is no significant difference between performance of conventional and Islamic retail and wholesale banks in respect to staff cost to income ratio, cost to income ratio, asset utilization ratio and operating efficiency ratio during the study period. The study found that there is a positive relationship between Staff Cost to Income Ratio, Operational Efficiency Ratio and Cost to Income Ratio among retail and wholesale Islamic and conventional banks. 


\section{RESEARCH METHODS}

The data obtained from this study were obtained by calculating quantitative descriptive analysis. Descriptive Quantitative Methods This study was conducted by way of comparing the available data and calculate changes in the Report n Finance PT. Bank Syariah Mandiri.

\section{Analysis Tools}

The analytical tool used in this research is to use financial ratio analysis, according to Irham Fahmi in his book Analysis of Financial Statements 2011 Financial ratios used are Liquidity Ratio ( Current Ratio, Quick Ratio, Cash Ratio ), Solvency Ratio (Debt To Ratio, Debt To Equity Ratio), Profitability Ratio (Net Profit Margin, Return On Investment (ROI) Return On Equity (ROE) ).

Financial Ratios (Sumantri, 2019)

\section{Liquidity Ratio}

a. Curret Ratio / Rasio Lancar

$$
\text { Curret Ratio }=\frac{\text { Aktiva Lancar }}{\text { Utang Lancar }} \times 100 \%
$$

b. Quick Ratio / Rasio Cepat

$$
\text { Quick Ratio }=\frac{\text { Current Asset-Inventories }}{\text { Current Liabilities }}
$$

c. Cash Ratio/Rasio Lambat

$$
\text { Cash Ratio }=\frac{\text { Cash }+ \text { Setara Kas }}{\text { Current Liabilities }}
$$

\section{Solvabiliy Ratio}

a. Debt To Total Assets atau Debt Ratio

$$
\text { Debt Ratio }=\frac{\text { Total Liabilities }}{\text { Total Assets }}
$$

b. Debt To Equity Ratio

$$
\text { Debt To Equity Ratio }=\frac{\text { Total Liabilities }}{\text { Total Sharenolder's Equity }^{\prime}}
$$

\section{Profitability Ratio}

a. Net Profit Margin / Rasio Laba Bersih

$$
\text { Net Profit Margin }=\frac{\text { Earning After Tax }(E A T)}{\text { Sales }}
$$

b. Return On Interest (ROI) / Pengembalian Investasi

$$
\text { Return On Interest }=\frac{\text { Earning After Tax }(\text { EAT })}{\text { Total Assets }}
$$

c. Return On Equity (ROE) / Laba Atas Equity

$$
\text { Return On Equity }=\frac{\text { Earning After Tax }(\text { EAT })}{\text { Sharenoldera's Equity }}
$$




\section{FINDINGS AND DISCUSSION}

\section{Financial Ratio Standards}

Standards To measure the limit value of financial ratios and assessment criteria for liquidity ratios, solvency ratios, and profitability ratios according to Kasmir (2013) suggests the following:

\section{Table 2. Criteria Ratio Value Limit}

\begin{tabular}{ll}
\hline Ratio Type Liquidity & $\begin{array}{l}\text { Minimum } \\
\text { Standard }\end{array}$ \\
\hline a. Current Ratio & a. $200 \% / 2: 1$ \\
b. Quick Ratio & b. $100 \% / 1: 1$ \\
& \\
c. Cash Ratio & c. $100 \% / 1: 1$
\end{tabular}
Information

a. Every Rp. 1 current debt guaranteed by Rp. 2 Active smoothly.

b. Every Rp. 1 current debt is guaranteed by Rs. 1 current asset fewer inventories.

c. Every $\$ 1$ of current debt is guaranteed by $\$ 1$ cash plus cash equivalents.

\section{Solvability Maksimal}
a. Debt Ratio
a. $50 \% / 1: 0,50$
b. Debt To Equity Ratio
b. $45 \% / 1: 0,45$

a. For every Rp. 1 of company funding, a maximum of Rp. 0.5 is financed by debt.

b. Every Rp. 1 incorporate funding a maximum of Rp. 0.45 is financed by debt.

\section{Profitability}
a. Net Profit Margin
a. $20 \%$
b. Return on Investment
b. $30 \%$

a. Every $\$ 1$ of sale can generate Rp.0.20 net profit after tax.

b. Every Rp. 1 of the assets used is capable of generating a net profit after tax of Rp. 0.30 la
c. Return on Equity
c. $40 \%$

c. Every Rp. 1 of capital used is capable of generating a net profit after tax of Rp. 0.40

Source: Results of data processing

Table 3. Value Criteria

\begin{tabular}{lcccc}
\hline \multicolumn{1}{c}{ Ratio of Finance } & $\begin{array}{c}\text { Very Poor } \\
(\boldsymbol{\%})\end{array}$ & $\begin{array}{c}\text { Poor } \\
(\boldsymbol{\%})\end{array}$ & Good (\%) & $\begin{array}{c}\text { Very Good } \\
(\boldsymbol{\%})\end{array}$ \\
\hline Likuidity & & & & \\
a. Current Ratio & $0-99$ & $100-199$ & $200-299$ & $300-400$ \\
b. Quick Ratio & $0-49$ & $50-99$ & $100-149$ & $150-200$ \\
c. Cash Ratio & $0-49$ & $50-99$ & $100-149$ & $150-200$ \\
\hline Solvability & & & & \\
a. Debt To Ratio & $100-76$ & $75-51$ & $50-26$ & $25-0$ \\
b. Debt To Equity Ratio & $100-69$ & $68,6-46$ & $45-23$ & $22,5-0$ \\
\hline
\end{tabular}




\begin{tabular}{lcccc}
\hline Profitability & & & & \\
a. Net Profit Margin & $0-9$ & $5-9$ & $10-15$ & $16-20$ \\
b. ROI & $0-20$ & $20-25$ & $25-30$ & 30 \\
c. ROE & $0-9$ & $9-15$ & $15-21$ & 21 \\
\hline
\end{tabular}

Source: Results of processing data

\section{Growth}

The Growth formula is as follows:

Growth $=\frac{\mathrm{Ta}-\mathrm{Td}}{\mathrm{Td}} \times 100 \%$

Information: $\quad \mathrm{Ta}=$ Year of Analysis

$$
\mathrm{Td}=\text { Base Year }
$$

\section{DISCUSSION}

The Growth Condition of the Liquidity Ratio of PT. Bank Syariah Mandiri Indonesia for the period 2014-2018

\section{Current Ratio (Current Ratio)}

In this ratio comparing current debt with current assets, the calculation of the current ratio at PT. Bank Syariah Mandiri Indonesia for 5 years as follows:

Table 4. Calculation of Current Ratio 2014-2018 At PT. Bank Syariah Mandiri Indonesia (In Million Rupiah)

\begin{tabular}{|c|c|c|c|c|}
\hline Year & $\begin{array}{c}\text { Current } \\
\text { Assets }\end{array}$ & $\begin{array}{c}\text { Current } \\
\text { Liabilities }\end{array}$ & $\begin{array}{c}\text { Current } \\
\text { Ratio }\end{array}$ & $\begin{array}{c}\text { Growth } \\
(\%)\end{array}$ \\
\hline 2014 & 64.516 .958 & 8.261 .583 & 7,8092 & - \\
\hline 2015 & 67.583 .068 & 9.460 .352 & 7,1438 & $(8,52)$ \\
\hline 2016 & 76.251 .955 & 10.801 .450 & 7,0594 & $(1,18)$ \\
\hline 2017 & 85.326 .671 & 13.113 .859 & 6.5066 & $(7,83)$ \\
\hline 2018 & 95.667 .408 & 14.037 .745 & 6,8150 & 4,73 \\
\hline \multicolumn{3}{|c|}{ Amount } & $\mathbf{3 5 , 3 3 5}$ & $(1,28)$ \\
\hline \multicolumn{3}{|c|}{ Average } & 7,0668 & $(3,2)$ \\
\hline
\end{tabular}

Source: Results of processing data

\section{Quick Ratio (Quick Ratio)}

In this ratio comparing current assets minus inventories with current debt, the calculation of the Quick Ratio at PT. Bank Syariah Mandiri Indonesia for 5 years as follows:

Table 5. Quick Ratio Calculation for 2014-2018 at PT. Bank Syariah Mandiri Indonesia (In Million Rupiah)

\begin{tabular}{ccccc}
\hline Year & $\begin{array}{c}\text { CA- } \\
\text { Inventory }\end{array}$ & $\begin{array}{c}\text { Current } \\
\text { Liabilities }\end{array}$ & $\begin{array}{c}\text { Quick } \\
\text { Ratio }\end{array}$ & $\begin{array}{c}\text { Growth } \\
(\%)\end{array}$ \\
\hline 2014 & 50.957 .671 & 8.261 .583 & 6,1680 & - \\
2015 & 58.739 .601 & 9.460 .352 & 6,2090 & 0,66
\end{tabular}




\begin{tabular}{rrrrc}
2016 & 73.356 .289 & 10.801 .450 & 6,7913 & 9,37 \\
2017 & 70.234 .031 & 13.113 .859 & 5,3557 & $(21,13)$ \\
2018 & 84.556 .998 & 14.037 .745 & 6,0235 & 12,46 \\
\hline Amount & & $\mathbf{3 0 , 5 4 7 5}$ & $\mathbf{1 , 3 6}$ \\
\hline Average & & $\mathbf{6 , 1 0 9 5}$ & $\mathbf{0 , 3 4}$ \\
\hline
\end{tabular}

Source: Results of data processing

\section{Cash Ratio ( Slow Ratio )}

This ratio is used to measure the company's ability to pay short-term obligations with available cash and stored in the Bank.

Table 6. Calculation of Cash Ratio 2014-2018 at PT. Bank Syariah Mandiri Indonesia (In Million Rupiah)

\begin{tabular}{ccccc}
\hline Year & $\begin{array}{c}\text { Cash + Cash } \\
\text { equivalent }\end{array}$ & $\begin{array}{c}\text { Current } \\
\text { Liabilities }\end{array}$ & $\begin{array}{c}\text { Cash } \\
\text { Ratio }\end{array}$ & Growth (\%) \\
\hline 2014 & 16.795 .305 & 8.261 .583 & 2,0329 & - \\
2015 & 18.029 .593 & 9.460 .352 & 1,9058 & $(6,25)$ \\
2016 & 22.077 .615 & 10.801 .450 & 2,0439 & 7,24 \\
2017 & 26.463 .894 & 13.113 .859 & 2,0180 & $(1,26)$ \\
2018 & 29.909 .923 & 14.037 .745 & 2,1306 & 5,57 \\
\hline Amount & & & $\mathbf{1 0 , 1 3 7 5}$ & $\mathbf{5 , 3}$ \\
\hline Average & & & $\mathbf{2 , 0 2 7 5}$ & $\mathbf{1 , 3 2}$ \\
\hline
\end{tabular}

Source: Results of data processing

Conditions for Growth of Solvency Ratio PT. Bank Syariah Mandiri Indonesia for the period 2014-2018

\section{Debt Ratio}

In this ratio, to find out the amount of debt that is in the company by comparing the total debt to total assets, the calculation of the Debt Ratio of PT. Bank Syariah Mandiri Indonesia for 5 years as follows:

Table 7. Calculation of Debt Ratio for 2014-2018 at PT. Bank Syariah Mandiri Indonesia (In Million Rupiah)

\begin{tabular}{ccccc}
\hline Year & $\begin{array}{c}\text { Total } \\
\text { Liabilities }\end{array}$ & $\begin{array}{c}\text { Total } \\
\text { Assets }\end{array}$ & $\begin{array}{c}\text { Debt } \\
\text { Ratio }\end{array}$ & $\begin{array}{c}\text { Growth } \\
(\%)\end{array}$ \\
\hline 2014 & 8.663 .174 & 66.955 .671 & 0,1293 & \\
2015 & 9.883 .107 & 70.369 .709 & 0,1404 & 8,58 \\
2016 & 11.232 .797 & 78.831 .722 & 0,1424 & 1,42 \\
2017 & 13.506 .681 & 87.915 .020 & 0,1536 & 7,86 \\
2018 & 14.477 .262 & 98.341 .116 & 0,1472 & 4,16 \\
\hline Amount & & & $\mathbf{0 , 7 1 2 9}$ & $\mathbf{2 2 , 0 2}$ \\
\hline Average & & $\mathbf{0 , 1 4 2 5}$ & $\mathbf{5 , 5 0}$ \\
Source: Results of data processing & &
\end{tabular}

\section{Debt To Equity Ratio}

In this ratio comparing the total debt to equity, the calculation of the Debt To Equity Ratio PT. Bank Syariah Mandiri Indonesia for 5 years as follows: 
Table 8. Calculation of Debt To Equity Ratio 2014-2018 At PT. Bank Syariah Mandiri Indonesia (In Million Rupiah)

\begin{tabular}{ccccc}
\hline Year & $\begin{array}{c}\text { Total } \\
\text { Liabilities }\end{array}$ & $\begin{array}{c}\text { Total } \\
\text { Equity }\end{array}$ & $\begin{array}{c}\text { Debt To } \\
\text { Equity Ratio }\end{array}$ & $\begin{array}{c}\text { Growth } \\
(\%)\end{array}$ \\
\hline 2014 & 8.663 .174 & 4.617 .009 & 1,8763 & \\
2015 & 9.883 .107 & 5.613 .739 & 1,7605 & $(6,17)$ \\
2016 & 11.232 .797 & 6.392 .437 & 1,7572 & $(0,43)$ \\
2017 & 13.506 .681 & 7.314 .241 & 1,8466 & 5,08 \\
2018 & 14.477 .262 & 8.039 .165 & 1,8008 & $(2,48)$ \\
\hline Amount & & & 9,0414 & $(4)$ \\
\hline Average & & 1,8082 & $(1)$ \\
\hline
\end{tabular}

Source: Results of data processing

With the Growth of (2.48)\%, this indicates a decreasing value compared to the previous year because the value of the Debt To Equity Ratio in 2017 was 1.8466 and in 2018 was 1,8008\%. So that in 2018 there was no Growth and decreased by $2.48 \%$.

Growth Conditions of the Profitability Ratio of PT. Bank Syariah Mandiri Indonesia for the period 2014-2018

This profitability ratio aims to determine how much the company's ability to earn profits in one period, this ratio is divided into 3 methods, namely:

Net Profit Margin

In this Net Profit Margin ratio, it compares the total amount of net profit after tax with the company's total revenue, which can be seen as follows:

Table 9. Calculation of Net Profit Margin in 2014-2018 at PT. Bank Syariah Mandiri Indonesia (In Million Rupiah)

\begin{tabular}{lccll}
\hline Year & EAIT & Sales & Net Profit Margin & Growth (\%) \\
\hline 2014 & $(44.811)$ & 5.487 .192 & $(0,008)$ & \\
2015 & 289.576 & 5.960 .016 & 0,048 & 500 \\
2016 & 325.414 & 6.467 .897 & 0,050 & 4,16 \\
2017 & 365.166 & 7.286 .674 & 0,050 & - \\
2018 & 605.213 & 7.688 .793 & 0,078 & 56 \\
\hline Amount & & $\mathbf{0 , 2 1 8}$ & $\mathbf{5 6 0 , 1 6}$ \\
\hline Average & & $\mathbf{0 , 0 4 3 6}$ & $\mathbf{1 4 0 , 0 4}$ \\
\hline
\end{tabular}

Source: Results of data processing

With a Growth of $56 \%$, this indicates an increased value compared to the previous year because the value of Net Profit Margin in 2017 was 0.050 and in 2018 was 0.078 . So in 2018, it has grown by 56 $\%$.

Return On Investment ( Pengemblian Investments)

Return on investment ratio (ROI) or return on investment, this ratio looks at the extent to which the investment that has been invested can provide returns as expected. And the investment is actually the same as the invested or placed company assets. 
Table 10. Calculation of Return On Investment in 2014-2018 at PT. Bank Syariah Mandiri Indonesia (In Million Rupiah)

\begin{tabular}{ccccc}
\hline Year & EAIT & Total Assets & ROI & Growth (\%) \\
\hline 2014 & $(44.811)$ & 66.955 .671 & $(0,0006)$ & \\
2015 & 289.576 & 70.369 .709 & 0,0041 & 783,33 \\
2016 & 325.414 & 78.831 .722 & 0,0041 & - \\
2017 & 365.166 & 87.915 .020 & 0,0041 & - \\
2018 & 605.213 & 98.341 .116 & 0,0061 & 48,78 \\
\hline Amount & & 0,0178 & 832,11 \\
\hline \multicolumn{5}{l}{ Average } \\
\multicolumn{5}{l}{ Source: Results of data processing } \\
\end{tabular}

With the Growth of $48.78 \%$, this indicates an increase in value compared to the previous year because the value of Return On Investment in 2017 was 0.0041 and in 2018 it was 0.0061 . So that in 2018 it experienced the Growth of $48.78 \%$.

\section{Return On Equity}

This ratio examines the extent to which a company uses its resources to be able to provide a return on equity.

Table 11. Calculation of Return on Equity in 2014-2018 at PT. Bank Syariah Mandiri Indonesia (In Million Rupiah)

\begin{tabular}{rcc}
\hline Year & Return On Equity & Growth (\%) \\
\hline 2014 & $(0,0094)$ & \\
2015 & 0,0592 & 729,78 \\
2016 & 0,0581 & $(1,85)$ \\
2017 & 0,0572 & $(1,54)$ \\
2018 & 0,0821 & 43,53 \\
\hline Amount & 0,2472 & 769,92 \\
\hline Average & 0,0494 & 192,48 \\
\hline
\end{tabular}

Source: Anual Report PT. Bank Syariah Mandiri Indonesia 2014-2018.

With the Growth of $43.53 \%$, this indicates an increase in value compared to the previous year because the value of Return on Investment in 2017 was 0.0572 and in 2018 was 0.0821 . So that in 2018 it experienced the Growth of $43.53 \%$.

Analysis of the Growth of Liquidity Ratios, Solvency, and Profitability Relationship with the Financial Performance of PT. Bank Syariah Mandiri Indonesia for the period 2014-2018

On the results of data processing financial statements. Bank Syariah Mandiri Indonesia, it can be analyzed the Growth of the Liquidity Ratio, Solvency, and Profitability related to its financial performance in the 2014-2018 period.

\section{Liquidity Ratio}

When viewed from the Liquidity Ratio based on the Current Ratio, Quick Ratio, and Cash Ratio calculation approaches, it is illustrated in the following table:

Table 12. Conditions of the Liquidity Level of PT. Bank Syariah Mandiri Indonesia according to the calculation of Current Ratio, Quick Ratio and Cash Ratio for the 2014-2018 period

\begin{tabular}{cccc}
\hline Year & Current Ratio & Quick Ratio & Cash Ratio \\
\hline 2014 & 7,8092 & 6,1680 & 2,0329
\end{tabular}




\begin{tabular}{cccc}
2015 & 7,1438 & 6,2090 & 1,9058 \\
2016 & 7,0594 & 6,7913 & 2,0439 \\
2017 & 6,5066 & 5,3557 & 2,0180 \\
2018 & 6,8150 & 6,0235 & 2,1306 \\
\hline amount & 35,335 & 30,5475 & 10,1375 \\
\hline Average & 7,0668 & 6,1095 & 2,0275 \\
\hline
\end{tabular}

Source: Results of data processing

\section{Solvency Ratio}

For the Solvency Ratio that has been stated above, in the 2014-2018 period the condition of the Solvency level of PT. Bank Syariah Mandiri Indonesia based on the Debt Ratio and Debt To Equity Ratio approaches is illustrated in the following table:

Table 13. Conditions of the solvency level of PT. Bank Syariah Mandiri Indonesia according to the calculation of the Debt Ratio and Debt To Equity Ratio for the 2014-2018 period.

\begin{tabular}{ccc}
\hline Year & Debt Ratio & Debt To Equity Ratio \\
\hline 2014 & 0,1293 & 1,8763 \\
2015 & 0,1404 & 1,7605 \\
2016 & 0,1424 & 1,7572 \\
2017 & 0,1536 & 1,8466 \\
2018 & 0,1472 & 1,8008 \\
\hline amount & 0,7129 & 9,0414 \\
\hline Average & 0,1425 & 1,8082 \\
\hline
\end{tabular}

Source: Results of data processing

\section{Profitability Ratio}

From the calculation of the Profitability Ratio, in the 2014-2018 period the condition of the solvency level of PT. Bank Syariah Mandiri Indonesia based on the Net Profi Margin approach, Return On Investment and Return On Equity is illustrated in the following table:

Table 14. Conditions of the level of profitability of PT. Bank Syariah Mandiri Indonesia according to the calculation of Net Profit Margin, Return On Investment and Return On Equity for the 2014-2018 period

\begin{tabular}{cccc}
\hline Year & NPM & ROI & ROE \\
\hline 2014 & $(0,008)$ & $(0,0006)$ & $(0,0094)$ \\
2015 & 0,048 & 0,0041 & 0,0592 \\
2016 & 0,050 & 0,0041 & 0,0581 \\
2017 & 0,050 & 0,0041 & 0,0572 \\
2018 & 0,078 & 0,0061 & 0,0821 \\
\hline Amount & $\mathbf{0 , 2 1 8}$ & $\mathbf{0 , 0 1 7 8}$ & $\mathbf{0 , 2 4 7 2}$ \\
\hline Average & $\mathbf{0 , 0 4 3 6}$ & $\mathbf{0 , 0 0 3 5}$ & $\mathbf{0 , 0 4 9 4}$ \\
\hline Source: data processing results &
\end{tabular}

These ratios have fluctuated a lot, if the percentage increases, the company management must continue to be consistent in optimizing sales, both in terms of maximum product or service. And if it decreases, the company must evaluate and improve.

By implementing these ratios, it will be easier for internal and external parties to know the percentage of profit or profit that PT. Bank Syariah Mandiri Indonesia. 


\section{CONCLUSION AND SUGGESTION \\ Conclusion}

Based on the results of research conducted at PT. Bank Syariah Mandiri Indonesia, it can be concluded that:

1. The Growth of the Liquidity Ratio for the 2014-2018 period seen from the Current Ratio approach, the highest figure was shown in 2014 at 7.8092 and the lowest in 2017 was 6.5066, while for the average Growth it was (3.2)\%. In the Quick Ratio, the highest number was shown in 2016 of 6.7913, and the lowest figure was in 2017 of 5.3557. Meanwhile, the average Growth is $0.34 \%$. In Cash Ratio, the highest figure was in 2018 of 2.1306 and the lowest was in 2015 of 1.9058. And for the average Growth of $1.32 \%$.

2. The Growth of the Solvency Ratio for the 2014-2018 period is seen from the Debt Ratio, the highest figure was shown in 2017 of 0.1536 and the lowest was in 2014 of 0.1233. Meanwhile, the average Growth is 5, $50 \%$. In the Debt To Equity Ratio, the highest figure was in 2014 of 1.8763 and the lowest was in 2016 of 1.7572 . For the growth rate of (1)\%.

3. The Growth of the Profitability Ratio for the 2014-2018 period is seen from the Net Profit Margin, the highest number in 2018 was 0.078 and the lowest was in 2014 (0.008). For the average Growth is $140.04 \%$. In the Return On Investment, the highest figure was in 2018 of 0.0061 and the lowest was in 2014 (0.0006). For an average Growth of $208.02 \%$. The highest Return On Equity figure was in 2018 of 0.0821 and the lowest was in 2014 (0.0094) and the average Growth value was 192.48\%.

\section{Suggestion}

1. Companies must maintain and increase their liquidity, namely the company's ability to pay off all short-term debts using the Current Ratio, Quick Ratio, and Cash Ratio.

2. Besides, the company must also maintain and increase its solvency, namely the ability of company assets to be financed by debt using the Debt Ratio and Debt to Equity Ratio.

3. And finally the company must increase its profitability, namely the company's ability to generate profits or profits by using Net Profit Margin, Return On Investment, and Return On Equity.

\section{REFERENCE}

Sumantri. (2019). Manajemen Keuangan (Moh. Nasrudin (ed.); 1st ed.). PT. Nasya Expanding Management. www.penerbitnem.com

Sumantri. (2020). Pengaruh Produk Bank Syariah Mandiri Terhadap Minat Menabung Masyarakat Kecamatan Muara Tembesi Kabupaten B. Citra Ekonomi, 1(1), 10.

Fahmi.Irham. 2011 Financial Statement Analysis, Bandung: Alfabeta.

Fahmi.Irham. 2012 Introduction to Financial Management, Bandung: Alfabeta.

Sujarweni V. Wiratna. 2017 Financial Management, Yogyakarta: Pustaka Baru Press.

Sujarweni V. Wiratna. 2019 Financial Statement Analysis, Yogyakarta: Prees New Library. 
Nursantiawati.Ratumas.2019 Analysis of Liquidity Ratios, Solvency, and Profitability of Financial Performance at PT. Garuda Indonesia (Persero) Tbk.

Yunita. 2017/2018 Analysis of Liquidity Ratio, Solvency, and Profitability at CV Bina Usaha, Muara Bulian District, Batang Hari District, 2011 to 2015.

Writing Team, 2019. Thesis Writing Guide. College of Economics Graha Karya Muara Bulian. https://www.mandirisyariah.co.id/tentang-kami/company-report/annual-report (accessed May 23, 2020).

https://www.jurnal.id/id/blog/analysis-leport-keuangan-dan-jenis/ (accessed June 5, 2020

https://cpssoft.com/blog/mana Manajemen /mana Manajemen-keuangan-pengentuk-fungsi-t Destinations-dan-ruang- lingkupnya/ (accessed June 5, 2020)

Ais Zakiyudin . ( 2012, June 22). Management According to Af Stoner and Charles Wankel, from http://ais-zakiyudin.blogspot.com/2012/06/mana Manajemen- menurut- james- af- stonerdan.html? $\mathrm{m}=1$

Rachman Buana . ( 2013, 6 October). Understanding management according to Mary Parker Follets and other opinions from http: //www.rachmanbuana. blogspot.com/2013/10/pengentukmanagement-dan-kepemerdekaan.html? $\mathrm{m}=1$

Hasibuan.Drs.H.Malayu SP2016. Human Resource Management. Revised Edition, Palembang : Bumi Askara

Dr. Badrudin , M.Ag, 2016.Basic Management, Bandung: Alfabeta.

M. Manulang , 2015 . Management Basics , Yogyakarta: GajahMada University Press

Dr. Kamaludin.Dr.RiniIndriani, Msi, SE, Akt, 2018. Revised Edition Management, Bandung : CV.MandarMaju

Rudianto, 2013 Management Accounting, Bandung : Erlangga

Sutrisno , 2009. Financial Management Theory Concepts and Applications, Yogyakarta: Ekonisia

Harahap.Sofyan Syafri, 2011. Critical Analysis of Financial Statements, Depok : Rajawali

Prof. Dr. Muhard, Dkk, 2013. Financial Management. Bandung : Refika Aditama

Munawir, 2010.Anaisis Financial Report, Yogyakarta : Liberty

Dr. Kasmir, SEMM, 2012. Introduction to Financial Management, Second Edition, Yogyakarta : Kencana

Hery, SE.M.Si. 2015. Financial Statement Analysis, Jakarta : Grasindo 